\title{
A Question of Ethics: The Creative Orthodoxy of Buddhist Monks in the Mongolian Gold Rush
}

Mette M. High, University of St Andrews

\begin{abstract}
Addressing the intersections of economic opportunities and scriptural interpretation, this article examines how Buddhist monks involved in the Mongolian gold rush view the ethics of mining. Commonly regarded an act of theft and violence within Mahāyāna Buddhism, mining is locally subject to strong ethical denunciations. Drawing on historical connections and transnational devotional practices, the mining monks engage creatively with a method of meditation known as 'breaking the mind', which offers a competing way of knowing the world. Focusing on the universe within which they conceptualize action, they present a radical reinterpretation of ethical human life. I argue that the mining monks' own conceptual framework highlights the analytical importance of attending to not only visible bodily action, but also people's self-reflection in our attempts to understand the place of the ethical in human life.
\end{abstract}

Key words: Ethics, Buddhism, gold mining, epistemology, Mongolia.

The gold mines of Uyanga extend as far as the eye can see. Black lingering exhaust fumes fill the air as the industrial excavators, dumper trucks, and front loaders teem along narrow dirt tracks between the deep open-pit mines and pools with stagnant green-tinted water. Looking across this barren, wind-swept valley on a cold autumn day in 2011, a friend of mine known as Batbold, who worked as a mining company supervisor, turned to me and said: "Do you remember how a few years ago there used to be thousands of ninjas (ninja) here?" The 'ninjas', he was referring to, were artisanal gold miners who had flocked to Uyanga in such numbers that it became known as the country's 'ninja capital' (ninja naryn nislel). Batbold continued his reminiscences: 
Pre-copyedited version! Final version published in Ethnos 2016. Mette M. High

Please access it here: http://www.tandfonline.com/eprint/YJvhqgeRKljkdmR2Y197/full

Do you remember how there used to be gers and tents (maihan) everywhere? And people had their mining holes and took the dirt down to the river to pan for gold? Now almost all the ninjas are gone. They have moved elsewhere. But it isn't because gold is no longer reaching (hüreh) us. We are still finding a lot of gold! It is harder, it truly is, and we do need the machinery. It is big business now. Not like before!

Batbold lit a cigarette and inhaled deeply before continuing.

Ninjas always talked about how there was no gold, do you remember? But they were talking nonsense (demii yum yarih)! Pure nonsense. There is plenty of gold. Now that we all have lamas working for us, we just stand there with our water jets and you can see the gold in the dirt. Now that every company has a lam uurhaich, it is no problem finding gold.

The Mongolian gold rush hit the remote mountainous region of Uyanga around the year 2000. As it unfolded, Buddhist monks, known locally as lamas (lam), became centrally involved in carrying out rituals for ninjas and other gold rush participants. Lamas were often consulted to specify auspicious moments for the initial 'breaking of the soil' (gazar höndöh). When a new mining-hole reached the gold deposit and the ninjas began 'branching out' (burzaih), lamas were often invited to the site to 'give offerings' (örgöl örgöh) to spirit beings that were said to hold, if not withhold, the precious metal. If an accident happened, the injured ninja was quickly taken to the monastery or the private homes of lamas for the 'readings of texts' (unshlaga unshih). And at times of illness and affliction, lamas were usually consulted for advice and treatment. As I have discussed elsewhere (Author 2013a), the advent of the gold rush became pivotal to the daily life and liturgy of Uyanga's religious specialists.

But although the village lamas have now been involved in the gold rush for more than a decade, the precise nature of this involvement has changed drastically over the years. As Batbold commented, the emergence of 'lam uurhaich', which can be translated as a 'mining monk' or a 'mining lama', has been particularly consequential. Swopping their maroon and amber robes and felt boots for old jeans and Chinese rubber boots, some of the village lamas 
Pre-copyedited version! Final version published in Ethnos 2016. Mette M. High

Please access it here: http://www.tandfonline.com/eprint/YJvhqgeRKljkdmR2Yl97/full

have now joined the mining companies in the warmer summer months as contract miners. Some of them drive the heavy machinery, while others work the high-pressure water jets. At the end of the mining season, they return to the monastery to work fulltime as lamas. The first time I heard about lam uurhaich was during a stay with one of my host families living on the steppe. It was an early morning when my host father initiated a conversation that I was well familiar with; a conversation in which he lamented the current state of affairs. The rain had not been forthcoming, the grass was not as green and tall as usual, the animals were not fattening up. I half-listened to the almost customary lament until he added: "And, now our lamas are 'washing dirt' (shoroo ugaah)! We, our Uyanga, now have lam uurhaich!" I must admit I initially scoffed at this and joined in my host father's lament. However, when I later began fieldwork with the mining lamas, I realized that I had to not only question my own readiness to deride the lamas' direct involvement in mining but also take seriously the ways in which the lamas conceptualized and reflected on their own actions. They emerged as far from apt instantiations of a Simmelian financialized universe where money come to envelop and express our fundamental sense of being (Simmel 1903:104). Earning money from mining has not led to the surrender of the lamas' sense of being to the mediating schema of exchange and the quantifiable value of money. Their 'personal substances' and collective 'way of life' have not been extensively homogenized through the prevalent circulation of the moneymediator so as to abolish their devotional practices and bonds with others. For the mining lamas themselves, monetary value and religious virtue are not mutually conflicting and this recognition has made them an important, if not unique, asset to the mining companies.

For Batbold and many of the other mining company supervisors, the direct involvement of lamas in the mining for gold has transformed the potential of gold mining in the region. In their eyes, it is an event that despite years of intense mining has now made gold even more accessible and more plentiful. As a result, most mining companies are keen to include 'mining lamas' in their work force and most companies today have at least one lam uurhaich working for them. Among the village lamas, however, it is an event that articulates and in turn produces growing frictions within an already divided monastic community. It is an involvement that highlights generational divides, pitching junior lamas against their seniors, bringing to the fore their differing understandings of how one ought to live and act. Reflections on and questions about ethical conduct have now become pressing, particularly among the lamas themselves. Based on extensive ethnographic fieldwork carried out between 
Pre-copyedited version! Final version published in Ethnos 2016. Mette M. High

Please access it here: http://www.tandfonline.com/eprint/YJvhqgeRKljkdmR2Yl97/full

2005 and 2011 in and around the monastery of Uyanga (Uyangiin Hiid), I will explore how the mining lamas position their mining activities in relation to classic Buddhist teachings and draw inspiration from transnational devotional practices. By looking at the intersections of an extractive economy and scriptural interpretations, I will show how a creative engagement with a Buddhist meditation practice has produced new and unexpected spaces for economic opportunities and ethical action in a monastic community.

In anthropology, there has been a concerted interest in ethics in recent years (see Cassaniti and Hickman 2014). Embracing different approaches, many of the exponents (e.g. Faubion 2011, Fassin 2008, Laidlaw 2002, Lambek 2010a, Zigon 2007) place their projects in contradistinction to the work and intellectual legacy of Durkheim. ${ }^{1}$ They draw attention to how Durkheim effectively aligned ethics with concerns about social norms, regularity, and control. Durkheim engaged Kant's conception of 'the moral law' and was interested in why rules received sanction and why following them appeared so attractive to people. But whereas for Kant (2005[1785]), 'the moral law' was a universal and a priori basis for acting in accordance with the demands of practical reason, thereby bringing attention to the role of reasoning, doubt and free will, Durkheim (2009 [1906]:35-62) saw 'moral facts' as socially constituted and revealing the particular structures of a society. As a codified representation of society, ethics thus became allied with understandings that mandate and motivate collective cohesion (Laidlaw 2002:312, 2014:22).

In an attempt to disentangle ethics from this nexus of social structure, power and ideology, Michael Lambek has in his recent work approached ethics as a constitutive part of the human condition that is grounded in "the complexity and perhaps inconsistency of human action and intention" (2010b:9). Approaching ethics as a communicative event, a dialectical movement between speech and action, Lambek seeks to move beyond Durkheimian ascriptions of fixity and certainty to reposition ethics within the plurality and nonconformity of human action. Inspired by Hannah Arendt's work on vita activa (Arendt 1958), Lambek draws on her insights into the unpredictability and irreversibility of action. For Arendt, this underscores the importance of promising and forgiving as mitigating faculties. 'Promising' reins in the unpredictability of action by binding actors to certain courses of events while 'forgiving' is a remedy against the irreversibility of action by absolving the actor from the unforeseen consequences of his/her deeds. This part of Arendt's work contemplates the possibilities for 
Pre-copyedited version! Final version published in Ethnos 2016. Mette M. High

Please access it here: http://www.tandfonline.com/eprint/YJvhqgeRKljkdmR2Yl97/full

what she calls a "practical politics" (1958:5): Possibilities for human beings to come together and act in concert when each one of them has the capacity to act and start something new of their own. In Lambek's exposition, however, her theory of action is considered in isolation from her work on vita contemplativa and the three faculties of thinking, willing and judging (Arendt 1971, 1982); capacities for contemplation and self-understanding that would seem so central to an action-based theory of ethics. ${ }^{2}$ Lambek turns instead to JL Austin's theory of speech acts and argues that it is the act of "speaking [that] entails and generates criteria" for ethical judgment (2010c:43). As such, it is through utterances that agents are manifested and disclosed (ibid.:51, see also 2015:129). Rather than valorizing the complexities and perhaps inconsistencies in contemplative life, 'action' becomes coterminous with 'interaction'. As a result, actions of the mind become relevant only in so far as they seek to engage other actors - acts by which "I accuse, command, condemn, confess, congratulate, criticize" (Lambek 2010c:51) to name just a few. But how are we to make sense of those forms of action that do not disclose themselves primarily through social relations and human speech $?^{3}$ That is, without implying some solitary process of self-understanding as Webb Keane mockingly presents (Keane 2010:82), how are we to make sense of the ethical independently of that which is spoken?

Rather than privileging familiar grammars, I suggest we take our starting point in acknowledging the diverse ways in which people comprehend and construct the world as a conceptual entity; that is to say, the particular epistemological constructions that people generate and favour. In the works by James Faubion (2011) and James Laidlaw (2014), palaces and farm houses, weather conditions and statistical calculations become actors that impinge on and influence human self-constitution and expression. This contingence affects legal and quotidian understandings of human agency, responsibility, and accountability. In an apt example offered by Laidlaw (2010:151), a sudden wind catches the curtains in a window, making them knock over a vase that falls on a passer-by's head. Here, a distributed chain of cause and effect reminds us that agency, responsibility, and accountability need not reside within a single individual, or indeed even a human being. In this article, I suggest that we need to ask not only to which entity we ascribe responsibility. We need to also ask the bigger question of what kind of conceptual totality people see themselves and their various others to be acting in. Rather than promoting a totalizing theoretical holism (Bubandt and Otto 2010:6), it is a call to recognize people's own reflections on the holistic epistemological 
Pre-copyedited version! Final version published in Ethnos 2016. Mette M. High

Please access it here: http://www.tandfonline.com/eprint/YJvhqgeRKljkdmR2Yl97/full

conditions of their existence. It is to ask: What kind of universe do people consider themselves and their others to be part of? The universe, understood here in its widest sense, is not necessarily one that is familiar to us. It is not necessarily one that we can presume to know. And this is something that has become central to the ethical understandings of gold mining, and human conduct more generally, among the village lamas of Uyanga.

\section{Buddhist ethics}

In Mahāyāna Buddhism, of which Mongolian Buddhism forms a part, the universe is seen to comprise multiple kinds of beings who all have Buddha as their shared teacher. Some of these beings are blissful gods reaping the fruits of past deeds. Others are violent demigods obsessed with wrath, pride, and jealousy. Again others are human beings, sharing the same physical world as animals and others. However, all these beings are not equally positioned to achieve the ultimate goal of freedom from suffering. Whereas beings born into lower realms are said to be driven by their delusive passions and desires, hence unable to rein in their untamed minds, humans are endowed with a rare and precious consciousness (oyuun uhaan, Pa. viñ̃āna) that enables actions of mindfulness, restraint, and compassion. In contrast to other beings, humans have obtained, what the Dalai Lama describes as, "the best form of existence for the practice of the Dharma" (1994:39). As one of Uyanga's lamas explained:

We are very fortunate to be human. Many beings don't have this high level of rebirth (deed törölt). Do you know how rare it is? Imagine an ocean, stretching as far as the eye can see. It is bad weather - it is windy and the waves rise very tall. On this ocean there is something floating, something like a life buoy (avrah tsagirag). It is thrown around by the waves. It doesn't lie still. Then imagine a blind sea turtle (dalain yast melhii) - it can't see what is above or below it. It just swims in the ocean and pops its head up once in a while. A human rebirth is as likely as this blind sea turtle popping its head up right into the life buoy. ${ }^{5}$

Reflecting on this exceptional rebirth of humans, the lama then added that we humans were probably one of the only beings that could carry out intentional action, that is, action that is 
Pre-copyedited version! Final version published in Ethnos 2016. Mette M. High

Please access it here: http://www.tandfonline.com/eprint/YJvhqgeRKljkdmR2Yl97/full

grounded in volition (zorilgoor, sanaatai). ${ }^{6}$ Such intentional actions are not only manifested outwardly through body and speech, but also inwardly through thoughts, desires, and emotions. All of these actions are central to progressing along the Hutagtyn Naiman Mör, or the Noble Eightfold Path, offering the way to the cessation of suffering. The lama slowly and carefully began listing its eight components:

1. Zöv üzel (right view)

2. Zöv uhaan (right intention)

3. Zöv üg (right speech)

4. Zöv üil (right action)

5. Zöv amdral (right livelihood)

6. Zöv hicheel zütgel (right effort)

7. Zöv durdal (right mindfulness)

8. Zöv samadi ${ }^{7}$ (right concentration)

He explained how all eight practices had to flow together, just like the nearby Ongi River (Ongiin gol). Rather than one drop of water being more important than another, all the drops come together and support each other in flowing the right way. But, he noted, although we humans are capable of acting intentionally, it is no guarantee for ethically sound action. As opposed to drops of water, we humans can intentionally commit sins (nügel) and stray away from the path. He emphasized how in the teachings of the Buddha, the human ability to distinguish and carry out good deeds was not restricted to or predicated on a particular Buddhist understanding of the world. It was also not presented as exclusive to the religious devout. Instead, the fundamental pillars of ethical life were shared by all of humankind regardless of personal faith, conviction, and practice.

As he made this point, he recited the sutra known as the Kālāma Sutta. Here, Buddha meets the villagers of Kālāmas in present-day Bihar, India. The villagers have received countless visits by other religious teachers who all have propounded their own doctrines and sought to tear down the doctrines of others. The Kālāmas are left deeply confused and approach Buddha in the hope that he might be able to advise them on how to live their lives in a morally proper way. After reassuring them that their state of confusion is completely understandable, he says to them: 
Pre-copyedited version! Final version published in Ethnos 2016. Mette M. High

Please access it here: http://www.tandfonline.com/eprint/YJvhqgeRKljkdmR2Yl97/full

Come, Kālāmas. Do not go by oral tradition, by lineage of teaching, by hearsay, by a collection of scriptures, by logical reasoning, by inferential reasoning, by reflection on reasons, by the acceptance of a view after pondering it, by the seeming competence of a speaker, or because you think, 'The ascetic is our teacher'. But when you know for yourselves, 'These things are wholesome, these things are blameless; these things are praised by the wise; these things, if undertaken and practised will lead to welfare and happiness', then you should engage in them (Thera and Bodhi 2011:66).

In the rest of the sutra, Buddha leads the Kālāmas to the realization that greed, hatred, and delusion lead to harm and suffering for oneself and others. Concluding that they should therefore abandon such actions, the villagers rejoice in the restitution of their moral clarity. In this teaching, Buddha shows how a life of reflection and moral restraint brings its own intrinsic rewards of happiness and wellbeing - whether or not people recognize the karmic laws of existence, another life after death, or the possibility of final liberation. Simply by taking up human bodily form, the Kālāmas are seen to possess the intellectual capacity to recognize and valorize the fundamental ethical distinctions that are central to Buddhist practice. ${ }^{8}$ It is thus by virtue of our consciousness rather than our faith that we can see the truth of the teachings.

In a country where the Buddhist establishment was aggressively repressed through decades of Soviet socialist anti-religious campaigns and reinstated in only 1991 (Kaplonski 2008, 2012), it is not surprising that the lama chose to recite this particular sutra. This is a region where people were not able to devote themselves openly and freely to Buddhist practice for several decades. It is also a region where lamas and laity continue to look towards Inner Mongolia, Tibet and India in particular for what they deem to be 'authentic' (jinhene) and 'true' (zöv ünen) practice. It was not long ago that one of the older village lamas worked as a math teacher at the local school and later as an accountant for a small company. And that one of the other older lamas struggled to hold down a steady job at the negdel (herding collective) due to his penchant for vodka. Today's older generation of lamas all have extensive personal histories that connect them to mundane jobs and ordinary lives independently of their extant Buddhist devotion. With an ethics that is grounded in the capacity for reflection rather than 
Pre-copyedited version! Final version published in Ethnos 2016. Mette M. High

Please access it here: http://www.tandfonline.com/eprint/YJvhqgeRKljkdmR2Yl97/full

years of devotion, these older lamas are today generally much respected by the laity.

Although they have only been able to practice openly in their adult years, their personal struggles, efforts and courage seem central to their present positions as 'moral exemplars' (Humphrey 1997:34, Atwood 2004:325). Some members of the laity remember how several lamas practiced in 'secret' despite facing the risk of imprisonment, if not death by shooting. Others assisted them in hiding old Tibetan books, silk wall hangings, and brass paraphernalia from the authorities. When the monastery of Uyanga was rebuilt in 1991, it was a major effort that was led by this older generation of lamas. They reinvigorated ritual traditions, reinstated ceremonial calendars, and re-launched the recruitment of novices. Addressed by the laity with the honorary title of bagsh ('teacher'), they are now generally regarded as central to the "professional rationalization of ethics" (Lambek 2010b:3). Given this position, they readily voice their damning charges if and when fundamental Buddhist tenets are being challenged. With the onset of the Mongolian gold rush around the year 2000, this older generation of lamas has become particularly vociferous.

\section{The flourishing of ignorance}

It all started around 1993 when the Mongolian mining company Erel began mining for gold a few kilometers from the village. This event marked the transformation of Uyanga into 'a place where people only live for themselves', as an elderly herder put it - into 'a place where nature (baigal) suffers'. Erel diverted and set up dams on the local river, which shortened its course and made the water undrinkable for people and animals living downstream. Erel used the river water for its water jets, which it directed at the gold-bearing valley floors. The resulting slurry was led through sluice boxes and tall heaps of waste tailings were left behind. Industrial diggers slowly worked their way up the valleys, followed by ninjas who arrived in their thousands and started panning the waste tailings for leftover gold. Eventually the goldcontent of the tailings was so minimal that many ninjas began the hard work of prospecting and digging new mining holes using only hand-made metal picks. They hauled the sacks of gravel to the surface and transported them to the nearby river for panning. After 10 years most ninjas have moved to new areas and the valleys are now being dug up predominantly by so-called huul' bus kompanuud, that is: 'Illegal companies'. These companies are called 'illegal' because they operate without an official mining license. Also, they are not selling the excavated gold to the official gold buyer, which is the Bank of Mongolia based in the capital 
Pre-copyedited version! Final version published in Ethnos 2016. Mette M. High

Please access it here: http://www.tandfonline.com/eprint/YJvhqgeRKljkdmR2Yl97/full

city of Ulaanbaatar. Lastly, they are also not paying income taxes or royalties on their discoveries. In a country where denoting an activity as 'illegal' does not necessarily entail a value judgment, the local reference to this latest wave of mining companies is more a statement of facts than a moral criticism (see also Roitman 2005:189). [insert photo]

Caption: 'Illegal companies' working in the gold mines of Uyanga, Mongolia (photo taken by the author, August 2011)

Among many of the village lamas, gold mining is seen as an incredibly dangerous activity. This is partly because gold is one of the so-called 'nine jewels' (yösön erdene). These include pearl, coral, turquoise, lapis lazuli, mother of pearl, steel, copper, silver, and gold. In Mongolia's past, these gems were ground up and used as pigments to handwrite Buddhist texts, thereby representing the gem-like quality of Buddha's teachings (see Zhengyin $2003: 618$ ). Given this particular use, gold is today often described as 'a very special and precious treasure that is connected to the gods'.

This connection, however, is more than one of symbolic representation. As I have discussed elsewhere (Author 2013a), gold is also seen to be 'held' (barih), if not 'withheld' (tatgalzah), by powerful spirit beings known as lus that dwell in and around water sources. As in the regional literature on Tibetan protective deities known as 'treasure guards' (de NebeskyWojkowitz 1956:253), lus are said to have adorned their dwelling places with gold. Staircases, walls, and floors are all made of gold, as is their armor if they have any. Sometimes they protect themselves with gold shields or brandish swords made of gold. At other times they drink from gold cups or curl themselves around enormous gold nuggets. In order for humans to obtain gold without 'stealing' from lus, it is therefore necessary to first try to persuade them to part with their treasure. If humans fail to do this, lus are likely to get angry and might inflict calamities such as illnesses and accidents. Desiring a metal that is so closely guarded and so destructive to extract, gold mining is considered a hulgain hereg, meaning 'an act of theft', potentially giving rise to a dogshin baidal, which can be translated as a 'state of violence'. Gold mining is considered a dangerous activity that entails a fundamental disregard of other beings. 
Pre-copyedited version! Final version published in Ethnos 2016. Mette M. High

Please access it here: http://www.tandfonline.com/eprint/YJvhqgeRKljkdmR2Yl97/full

Yet, lamas recognize that this human disregard for others is not necessarily intentional. Although human beings within Buddhist cosmology enjoy an exceptional rebirth where intentionality is one of our distinguishing features, it does not necessarily direct all of our actions. Indeed, sometimes Uyanga's miners are seen to be incapable of controlling what they do. In the region, the gold rush is described as a kind of centripetal force that pulls (tatah) people in. "We can't move away from the mines", a ninja once commented when she and her husband failed to move back to the steppe. "Every time we try, we are pulled back" (tatagdah). She made a fist and pulled it strongly in a direct line towards her body. Batbold, mentioned in the opening vignette, similarly felt that there was "a strong thing" (hüchtei yum) in Uyanga. Placed in opposition to this force, miners are often described as 'having little strength' (chadal bagatai). This severance of action from intention is said to be a manifestation of the so-called altny chadvar, meaning 'the power of gold'. Now flourishing in Uyanga, this is an invisible substance that is said to emerge when people extract the heavy and dangerous gold. Given its invisibility, the materiality of altny chadvar is little known but some people describe it as a sort of 'invisible dust' (haragdahgüi shoroo) that rubs off gold during the process of extraction. When people come into contact with this, an 'illness' (övchin) spreads among its victims; an illness that has one dominant symptom: Namely, an obsessive longing or greed for the precious metal.

Important for this discussion, Marilyn Strathern (1997:142) has observed that actions that are carried out unconsciously, for example under the influence of sorcery, are often not subject to the same moral evaluation as conscious actions. In this sense, unconscious actions may be regarded as amoral rather than immoral. This is also the case in Uyanga where the potential presence of altny chadvar unsettles any quick and easy denunciation of miners' actions. Rather than mining being a clear act of human volition, altny chadvar is deemed partly responsible for the continuation of the mining boom. However, it does not relieve miners of the moral judgment as to why they decided to join the gold rush in the first place. Indeed, it only intensifies the question. Why did they decide to go to the mines in search of this precious treasure connected to both gods and lus when altny chadvar makes it so hard to leave the mines again? Why are people willing to risk the loss of their own strength by joining the gold rush? 
Pre-copyedited version! Final version published in Ethnos 2016. Mette M. High

Please access it here: http://www.tandfonline.com/eprint/YJvhqgeRKljkdmR2Yl97/full

Many miners deflect such questions by emphasizing that the potential interaction with and influence of nonhuman forces in human life is part of the conditions of human existence. Whether or not you are a miner, your 'strength' (chadal) is always subject to the ebbs and flows of fortune and other forces (Humphrey and Ujeed 2012). Rather than being discrete and separable, fixed and defensible, it is subject to much speculation and sense-making. As such, the illness-inflicting invisible dust of altny chadvar is seen to exemplify more generally the dangers and demands that are placed on people when they try to make a living.

For many village lamas, however, miners are not really trying to make a living. Instead they are perceived often to spend their money in ways that lead to waste, indulgence, if not violence (Author 2013b). In voices of exasperation, lamas told me how they wished miners would spend their earnings differently. If only they would spend it on basic provisions such as food, shelter, or clothing, they would lament. Then mining could perhaps bring something good. But with seemingly constant village-wide drinking binges and fights, many lamas insisted that gold mining was 'completely unnecessary' (ogt hereggüi) for people. One of the senior lamas in the village, known as Budlam, had lost one of his sons in a drunken brawl and was a particularly fervent critic of the mining boom. ${ }^{9}$ Having just returned from a much anticipated wedding involving the son of a mining company boss and a local villager, Budlam, still in a drunken daze, reflected,

Human beings can live as long as they have water and air. If the air disappears or gets polluted, humans will die. That's the end. If the water disappears or gets polluted, humans will also die. All living things will come to an end. So then, water and air are more precious than gold. Gold isn't necessary for humans. It will lead to our extinction (möhöld hüreh).

He paused before continuing,

Our Uyanga has become a place of mining, a place of gold. But we lamas can’t accept (zövshöörch chaddaggüi) the mining. It's so wrong! It's a sin (nügel) committed by people who think only of themselves. This mining is leading humanity (hünii yas, lit. the bones 
Pre-copyedited version! Final version published in Ethnos 2016. Mette M. High

Please access it here: http://www.tandfonline.com/eprint/YJvhqgeRKljkdmR2Yl97/full

of humans) to its own destruction. And, even some of our own lamas are now mining. They are searching for gold too! They are destroying themselves and destroying the universe (yertönts)! This isn't right.

People here have become ignorant (munhag). They are trying to make Buddhist philosophy easier for their own lives. Ignorance is when a person tries to make it suit his life. But this is impossible. You can't change Buddhist philosophy because it has been tested through thousands of years. Manipulating this science is ignorance.

Many of Uyanga's lamas are now concerned that the flourishing of ignorance has entered the monastery itself. In a region where none of the lamas have taken the vows of monkhood, there is no monastic discipline or moral code (sahilga, Pa. vinaya) to which they must adhere and accordingly, no formal sanctions when they are seen to stray (see also Bareja-Starzynzka and Havnevik 2006:221). With no possibility for disrobing lamas, there is no enforced orthopraxis that can lend the monastic community its unity and harmony. By taking part in the gold rush, the mining lamas are thus accused of disregarding not only the content of the teachings, but also enforcing conflict within the local monastic community.

\section{Lam uurhaich}

One of the village lamas involved in the gold mining is Mönherdene - Budlam's oldest son. Mönherdene joined Uyanga monastery in the mid1990s and had always wanted to become a lama. As a child, he used to steal glances of his father's strange-looking texts and eagerly awaited the moment when he was allowed to ring the bell during recitations to summon the gods. Initially he spent the mornings at the village school and the afternoons studying the texts together with the other novices at the monastery. When he finally graduated from school, he made the transition to fulltime lama by joining his father and other lamas in the daily recitation of texts at the monastic 'meetings' (hural). A few years ago he married his long-term girlfriend and they moved to their own ger in his father's compound half a mile from the monastery. Soon thereafter they had their first child - a scenario that is common among Mongolian lamas. Drawing on his personal contacts, Mönherdene then asked a mining company supervisor for work. Having some experience driving regular cars, he was offered a 
Pre-copyedited version! Final version published in Ethnos 2016. Mette M. High

Please access it here: http://www.tandfonline.com/eprint/YJvhqgeRKljkdmR2Yl97/full

job the following spring as a dump truck driver, hauling dirt from the open-pit gold mine. He explained to me how he wanted this job in order to make some much-needed money for his family. As a junior lama, he received a monthly salary of only 60'000MNT (approx. 50USD), roughly half of his father's base salary from the monastery. Moreover, junior lamas were rarely invited to carry out personal readings or participate in ritual events outside the monastery, which provided more senior lamas with a substantial additional income. Before I first met Mönherdene, Budlam described his son's arrangement to me. He had just returned from the mines where he had done extensive readings together with two other village lamas at the request of a troubled mining company owner in significant debt. In a tired and exhausted voice, Budlam explained:

Our son does readings at the monastery. But he can't be a lama with a wife and child on such a low income. It's hard. So he goes to the mines in the summer and doesn't attend our meetings. If he doesn't have any other jobs this winter, he might try to come back to the monastery and read with me again. But he might also find that he can't be a lama anymore.

The mining company pays Mönherdene a monthly salary of 300'000MNT (approx. 250USD) and has mentioned potential pay increases as his skills and experience improve. Since there are few other jobs available in the region and hardly any that will offer that kind of salary, Mönherdene considers himself lucky to have landed a job in the mines - even if it has given rise to many clashes with his parents and senior lamas at the monastery.

It is not unusual in Mongolia for lamas to take up paid employment to supplement their income from monasteries (Kollmar-Paulenz 2003:23). According to the lama administering the monastery in Uyanga (da lam), there were about 60 initiates between 2000 and 2010. He estimated that about half of them have since left the monastery in order to take up other forms of employment. Of the remaining 30 or so junior lamas, some still live with their parents and siblings, managing to get by on their meagre salary. However, for those who have married, it has been necessary to find additional sources of income in order to support their wives and children. Yet, when the gold rush began around the year 2000, the lamas did not join the rush. And when I conducted fieldwork in the mines with ninjas in 2005 and 2006, I did not meet or 
Pre-copyedited version! Final version published in Ethnos 2016. Mette M. High

Please access it here: http://www.tandfonline.com/eprint/YJvhqgeRKljkdmR2Yl97/full

hear of any lam uurhaich. According to the da lam, in those years junior lamas mostly sought employment as drivers or contract herders. However, in recent years, with more than 30 ‘illegal companies', each company having approximately 20 employees working 5-7 days a week, the mining companies have now become key employers for married junior lamas in Uyanga.

One day Mönherdene took me on a trip through the mines and showed me his truck. He had decorated the inside of the cab with blue silk scarves (hadag) and hung talismans of guardian spirits (sahius sahigch) from the rearview mirrors. He had also glued a small plate of incense (utlaga) to the truck's dashboard and taped a handwritten mantra above the front driver's door. This, he explained, was to ensure that his mind stayed on the 'right' (zöv) path and to ward off the unwanted forces that he deemed omnipresent in the area. As he said,

If you are not careful when you mine, bad things will happen. Many people are not careful so I have to protect myself.

A particular concern for Mönherdene was the presence of altny chadvar. Given the importance of consciousness for his Buddhist practice as a lama, the affliction of altny chadvar would be detrimental to his future in the monastery. Once, in a serious tone, he admitted that if ever afflicted, his father would be right - then he would not be able to return to the monastery. Like Mönherdene, other lam uurhaich also actively seek to protect themselves and have similarly furnished their front loaders, diggers, and trucks. Working in an area where acts of violence and theft against other beings are said to flourish, evidence of the dangers involved in mining is plentiful. Only a few weeks earlier a man operating a digger died under a landslide. The miners saw this as evidence of $l u s$ punishing humans for their wrongdoings. According to Mönherdene, several of his lay co-workers do not display appropriate respect for lus. Instead of engaging lus through caring and good thoughts, through beckoning and propitiating them to part with their treasure, Mönherdene described how the miners triumphantly mine the ground and celebrate the gold coups. They dare each other to excavate further into the caving hillsides and dig deeper craters. In his view, these careless challenges are meant to test not only the miners' courage and the limits of the dangerous mining landscape but also the angered lus. "Lus nüdgüi”, he said - meaning, 'lus have no eyes'. With lus attacking randomly or blindly, it does not necessarily take its anger 
Pre-copyedited version! Final version published in Ethnos 2016. Mette M. High

Please access it here: http://www.tandfonline.com/eprint/YJvhqgeRKljkdmR2Yl97/full

out on the perpetrator. Instead it may attack anyone who has crossed the perpetrator's path. In a busy working environment where people work closely together, it means that dangers are imminent, also for the mining lamas.

Although the senior lamas are also involved in the gold rush, they make a key distinction between their own involvement and that of their juniors: The younger generation at the monastery has sought a source of income that is predicated not on appeasing but angering lus. Instead of respecting other beings, it entails causing them harm. This is an ethical distinction that for the senior lamas renders the generated income sinful and emblematic of a straying mind, that is, a mind that harbors wrong and harmful thoughts. As such, the bodily actions of mining are entangled with the physical object of money as well as the contemplative faculty of mind. While the mining company supervisors applaud the junior lamas for helping them to make gold more accessible, the senior lamas condemn the juniors' willingness, if not eagerness, to work for the mining companies. Rather than respecting the multiple beings with whom humans co-exist, they are seen to act as if they were 'free' (chölöötei) and the universe was 'empty' (hooson), as if their actions entailed no interaction. But how is it possible to embrace such a detached and autonomous view of being only to actively seek a return to the monastery six months later to join the senior lamas in the daily readings?

\section{Creative orthodoxy}

There is a cluster of Mahāyāna writings that endorse a radical reinterpretation of Buddhist ethics. ${ }^{10}$ These writings present ethics as conditional on how far humans have progressed on their spiritual path. The further they have progressed, the more they morally can, and indeed should, do - even to the extent of committing acts of violence. Buddhist scholar Paul Williams notes how "we may not always like the fact that Mahāyāna Buddhism permits killing, but the texts are there and are as much part of Buddhism as a historical phenomenon as are the acts themselves" (2009:164-165). In these Mahāyāna texts, ethics becomes a flexible and debatable issue that depends not only on whether or not someone is human, but also what kind of human.

Although these Mahāyāna texts have been central to various transgressive Buddhist practices (Harvey 2001:141-146, Jones 2008:80, Victoria 2006:225), Mönherdene and other lam 
Pre-copyedited version! Final version published in Ethnos 2016. Mette M. High

Please access it here: http://www.tandfonline.com/eprint/YJvhqgeRKljkdmR2Yl97/full

uurhaich in Uyanga do not appeal to these texts when considering the ethics of their actions. They do not consider themselves to have progressed so far on the spiritual path that they can embrace a revised code of ethics. Instead they have delved into the realm of consciousness and begun to engage broader questions of Buddhist metaphysics.

We were in the mines when Mönherdene encircled his body with the fragrant smoke of burning juniper incense (arts) and said,

I know you probably don't meet many lamas mining. But you know what? In Buddhism the main principle is that everything depends on karma. Man carries out actions through the body, through the tongue, and through the mind. You have to distinguish between these actions because they are not all the same. Remember, it is only the sin that is done by the mind that is heavy and serious. This is because the mind is like the 'Tsar' in Russia. What really matters is the mind.

Conceptualizing actions of the mind as having greater karmic consequences than actions of the body and the tongue, Mönherdene and the other mining lamas strive to ensure that their mind stays on the 'right' (zöv) path and is not clouded by the poisonous forces that they see burgeoning in the mines. To achieve this, they draw on the insights of a fellow village lama who has journeyed far away from Uyanga and become a so-called 'high sutra lama' (deed hölgönii lam).

In the early 1990s, a boy called Amartüvshin joined the monastery alongside numerous other boys from local families. Elderly lamas quickly noticed how gifted he was. Amartüvshin acquired the Tibetan phonetics at an impressive speed and studied the texts with apparent ease and deep interest. Yearning for a more rigorous environment, he left after a few years for Ulaanbaatar where he joined the newly established monastery Pethub Stangey Choskhor Ling Hiid, founded by the late reincarnate lama Kushok Bakula Rinpoche from Ladakh. In contrast to most other Mongolian monasteries, this monastery places particular emphasis on the strict adherence to moral precepts. It follows a monastic regulatory framework consisting of 253 vows known as Mülasarvāstivāda Vinaya. In the year 2000 the Rinpoche decided at the age of 83 to return to India and he invited Amartüvshin along. When the Rinpoche passed away 
Pre-copyedited version! Final version published in Ethnos 2016. Mette M. High

Please access it here: http://www.tandfonline.com/eprint/YJvhqgeRKljkdmR2Yl97/full

three years later, Amartüvshin sought to join the monastery where his teacher had received his education in the 1920s and 1930s. But due to Chinese government control, Amartüvshin could not enter the institution in Lhasa and travelled instead to a Tibetan refugee settlement in South India where one of the subdivisions of the monastery is located: The Drepung Gomong Monastery, which is one of the most influential monasteries for the advanced study of Tibetan Buddhist texts and meditation practice. Amartïvshin is still based at the monastery in South India and occasionally returns to Uyanga. His visits are surrounded by huge anticipation and excitement. Large prayer ceremonies, lavish celebrations, and focused meditation classes are held. And it was during one such visit in the summer of 2006 that Mönherdene and the other lam uurhaich began to learn more about the doctrines of Yogācāra, or what they call 'the method of breaking the mind' (setgeliin nomhotgolyn $\operatorname{arga})^{11}$ : A meditation practice that they say 'break in', 'tame' or 'pacify' the unruly animallike mind until it accepts its rider.

That summer Amartüvshin held a week-long course in meditation involving a series of preliminary exercises that were intended to assist the interested village lamas in establishing the right frame of mind. Since meditation practice is not usually part of the monastic day in Uyanga, he was said to have focused on the classic Tibetan Buddhist text called Stages of Meditation by Kamalaśîla (Tib. sGom Rim, Skt. Bhāvanākrama). It is a three-part text, which describes how a spiritual path can be developed in the mind of a meditator. On the very last day of his teaching, he was said to have introduced the village lamas to a brief versified text which is one of the fundamental texts for Yogācāra practice ("Thirty Verses on Consciousness Only" by Vasubandhu, Skt. Triṃsikāa-vijñaptimātratā). One of the other lam uurhaich known as Gansüh described to me how the insights of the text immediately resonated with him but Amartüvshin's visit was already coming to an end. Left without a teacher to introduce him to more Yogācāra reflections, Gansüh studied the 'Thirty Verses' and some of its commentaries largely on his own. Eventually, when Amartüvshin returned the following year, he was said to have added other Yogācāra texts and a concerted group of devotees began to form. However, with Amartüvshin only making brief and occasional visits, the devotees received limited guidance in their fervent study and application of insights. This absence of a teacher opened up a novel devotional space in which the novices engaged and applied their committed practice. 
Pre-copyedited version! Final version published in Ethnos 2016. Mette M. High

Please access it here: http://www.tandfonline.com/eprint/YJvhqgeRKljkdmR2Yl97/full

Gansüh began gold mining around year 2010. His son was approaching 2 years of age and his wife was pregnant with their second child. Like Mönherdene, Gansüh needed to earn more money for his family than he was receiving from the monastery. For Gansüh, gold mining became an occasion for training his mind. "I'm just a low sutra lama", he explained. "I can't work with my mind all the time". So when he left his compound in the early morning and drove across the river to the mining valleys, he began various meditation exercises. He told me how he reflected on how it is that we know things and why we cling on to our 'interpretations' (tailbar) so much so that we 'mistake' (anduurah) our own projections of the world for the world itself. He did not question whether or not gold really existed. Rather, he questioned the desire, grasping, clinging and longing for gold and the way in which such experiences affected his perceptions of actions surrounding gold. For him, gold mining seemed to habitually bring into being a world of interpretation in which there were 'two things' (hoyor yum) on opposite sides: him and gold, miners and the land, company bosses and money. "Always two things" (dandaa hoyor yum), he said emphatically. When mining for gold, it was tempting to interpret 'humans' (hümü̈is) as pitched against gold and its associated entanglements (alt malt). Echoing the words of a Yogācāra scholar, it is a scenario in which "individual beings are caught in the dual appearances of an observer and an observed, a 'knower' and what is 'known'” (Devenish 2012:13). Gansüh thus tried to question his own desire, grasping, clinging and longing, and reflected on the obstacles that prevented him from seeing the 'true conditions of human life'. Or, as he put it, 'the complete truth' (tögs ünen): A truth that did not involve such dual confrontations.

Significant for this article, a key contributor to these false interpretations is language: Yogacārins contend that "language never directly refers to anything but itself" (Lusthaus 2013:29). It is a system of self-referentiality and self-closure where "the act of reference operates by foisting the illusion that what is being referred to 'exists' outside the realm of language" (ibid:58). That is to say, when we make use of language, we effectively alter and distort our perceptual stream, engaging in a phenomenological reduction that creates, often imperceptibly, 'objects' as if they existed outside of consciousness, as if there was a world of permanence. Grammars are considered central to this illusion. When sharing a grammar with others, we participate in a system that extends beyond ourselves. Grammars are not subject to the spatio-temporal limitations of any individual nor our emotional or experiential states. For those unaware, our adoration of language can consequently give rise to the illusion of all 
Pre-copyedited version! Final version published in Ethnos 2016. Mette M. High

Please access it here: http://www.tandfonline.com/eprint/YJvhqgeRKljkdmR2Yl97/full

things, including our-selves, as having a permanence and unconditionality that we find comforting and reassuring, desirable and pleasurable. Rather than generating and instantiating ethical criteria as Lambek (2010a) suggested, language in the abstract (grammar and semantics) as well as in its ordinary use (pragmatics) is here considered a potential obstacle to critical awareness and ethical judgment. But this does not mean that Yogacārins are promoting silence or an alternative language. Instead Yogacārins contend that it is crucial to critically reflect on and be constantly aware of how we use language. Otherwise our language use will merely reinforce self-centered desires and attachments, inhibiting us from ever overturning our erroneous interpretations of the world. By engaging in meditation, coming to understand the world as having no enduring or finite elements set in opposition to each other, it is said that we will be able to experience, through our awareness, things as they really are (Pa. tathatā, often translated as 'such-ness').

This meditative focus is central to how Gansüh, Mönherdene and the other lam uurhaich envision the ethical pillars in their lives. For them, what happens in their minds, escaping the notice of others, is central to the karma they accrue. Following vows, observing customary rules, and taking part in monastic routines will not lead them further on their path without them also understanding how the world truly is. A lama can refrain from taking life but as long as his mind 'runs like a horse' (aduu shig güih) and creates projections of an unconditional permanent universe, he has not progressed on his path. He remains caught within a false reality of self-centered misperception. Instead of focusing narrowly on the ethical merits of particular actions, Gansüh, Mönherdene and the others consider the real ethical work to reside in the conceptual totality that they create for themselves. If they unknowingly endorse the dualist tendency of human perception, they will not be able to judge the ethics of human conduct and instead continue to feed a self-centric view of human existence.

While the Yogācāra doctrine concerns a broad range of fundamental epistemological questions, Uyanga's lam uurhaich engage mostly issues surrounding developing this socalled 'right view'. I suggest that this is partly a reaction to the devotional practices of the older lamas at the monastery. For Mönherdene, the older lamas including his own father place too much emphasis on actions of the body and the tongue. As a result, they not only privilege the human body and language as the main vehicles through which we carry out 
Pre-copyedited version! Final version published in Ethnos 2016. Mette M. High

Please access it here: http://www.tandfonline.com/eprint/YJvhqgeRKljkdmR2Yl97/full

actions, but also ignore the relationship between bodily action, language and perception. This, he lamented, lead to a marginalization of that which is significant about the human state of being: namely, our consciousness. Rather than engaging in acts of violence and theft, he considers his mining actions to also involve powerful meditation, which creates spaces of continuity rather than confrontation - spaces where the miner and the land cannot be presumed to be opposed or even separate. As Mönherdene explained,

In the old days, when people meditated a lot and their mind became pure, they could walk to India on foot in only three days. Or get to the top of mountains, like the one over there, in just three steps. They could walk faster than wild horses. They could walk faster than cars. They would simply close their eyes and call forth the places they wanted to reach. They would get there simply by seeing them with their eyes, by thinking about them. That's because nature is empty. There is nothing. So with their mind, they could pull it, roll it, and set foot on it. Now there's no one like that in Mongolia! They have all been killed. But there will be some again in the future. Someone like Amartüvshin might reach a state like that.

In this kind of universe, it is not actions of the body and the tongue that are first and foremost subject to moral scrutiny, but the state of the mind. What counts, even for novice practitioners like Mönherdene, Gansüh and the others, is the extent to which they try to dissolve conceptual dualities. When they get accused of disregarding other beings during mining, it is for them an accusation which reduces all action to only that of the body. It is an accusation, which privileges the visible and material body as the primary, if not only, locus of agency and overlooks the importance of human consciousness. Since it is by virtue of our consciousness that we can reflect on how we live our lives in the present, on how we reside together with other beings, their creative application of Yogācāra doctrine can be seen to offer the mining lamas a greater range of permissive actions than currently available to the other lamas. They have created a new and unexpected space within which they justify seemingly unwholesome bodily actions by claiming to hold non-objectifying thoughts. 
Pre-copyedited version! Final version published in Ethnos 2016. Mette M. High

Please access it here: http://www.tandfonline.com/eprint/YJvhqgeRKljkdmR2Yl97/full

\section{Conclusion}

In the remote mountains of Mongolia, a group of village lamas have turned to new devotional practices that differ markedly from the orientation of their monastery. Drawing on historical connections and personal relations that extend far beyond national borders, the lam uurhaich engage passionately and innovatively with classic scriptures that offer a competing way of knowing the world. In the absence of local teachers who can offer guidance and instructions, the young devotees explore novel convergences between the doctrine and their work in the mines. Since the soteriological path of Yogācāra requires a deep and critical venture into the realm of consciousness, its followers present a radical reinterpretation of human action and its ethics. Rather than seeing gold mining as an act of violent confrontation with and greedy theft from other beings, the mining lamas claim that their method of meditation has made a different world knowable. As they excavate and haul the gold-rich dirt, their bodily actions may appear similar to those of any other miner. But for them, the totality within which they conceptualize their own actions is significantly different. As they see the land folding under their machinery and they encourage lus to share the riches, the devotees remind us that their way of understanding the world is not simply a trivial matter of description or secondary elaboration. Instead, it constitutes the very condition for self-understanding and other-relating. It is, for them, the realm within which ethical judgment becomes an actual possibility.

This turn to new devotional practices is centrally linked to the material and economic aspirations afforded by the Mongolian gold rush. In a region of limited income opportunities, gold mining has suddenly brought unprecedented amounts of wealth within reach of its various residents. Bringing celebrity 'high sutra lamas' like Amartüvshin to this distant village, welcoming them with large prayer ceremonies and lavish celebrations, the booming gold wealth has also enabled younger lamas to continue their poorly paid monastic practice. By recognizing this economic reality, we should, however, not underestimate the existential dimensions of devotional practice. As Mönherdene, Gansüh and the others have demonstrated, 'breaking the mind' is as much about their generation of karma, their place in the universe, their dualist mind, as about anything else. Meticulously engaging multiple projects, they demonstrate how local religious practice exceeds its basic instrumentality. When we take seriously their engagement with Buddhist metaphysics and attend to their own ruminations, we can see how the teachings become imbricated with the devotees' own material, ethical, and philosophical undertakings. And we can also see how questions of ethics 
Pre-copyedited version! Final version published in Ethnos 2016. Mette M. High

Please access it here: http://www.tandfonline.com/eprint/YJvhqgeRKljkdmR2Yl97/full

hinge on culturally meaningful ways of conceptualizing actions that take place in a universe that we cannot presume to already know.

Rather than arguing that the epistemological underpinnings of human life are so at odds as to be "incommensurable" (Povinelli 2001), I have in this article shown that we should give them due attention. For a discipline that seeks to understand what it means to be human, it is necessary to engage questions of 'what it is to know' (Toren and Pina-Cabral 2009). Cheryl Mattingly (2012) has recently urged that anthropologists interested in understanding ethical life should pause for a moment and reflect on their theoretical presuppositions. Depending on such presuppositions, questions of epistemology can risk getting pushed into the background and not appear as important to the human condition as experienced by the people we seek to understand. As she notes, anthropologists have "been more comfortable with explanatory frameworks that emphasize the social and structural" (2012:179, see also Robbins 2007:295). With a theoretical proclivity for social structure and relational analysis, anthropological studies of ethics have remained firmly within a "sociological imagination" (Mills 2000, cf. Yan 2011) that sees social interaction as the presumed and exclusive locus of ethical judgment and experience. But why draw on theoretical frameworks that value the social to such an extent that it is accorded a universality and primacy that leaves little analytical space for individual self-reflection?

I wonder if this proclivity is a response to an unease with the long-standing and influential tradition of moral philosophy and a view that "philosophers..do not concern themselves with locating the moral subject within social and cultural worlds" (Howell 1997:7). Is it because we assume that in order for us to make sense of those forms of action that do not disclose themselves primarily through social relations and human speech, we must draw on atomistic theories of moral action? Is it because an attempt to understand people's self-reflection is feared to edge closer to a moral philosophy interested in pure and abstracted reason? Or is it maybe because anthropologists have taken to heart insights from psychology and cognitive sciences that people's "self-knowledge is limited and untrustworthy" (Keane 2010:66)? That Descartes's trust in our faculty for reasoning and self-skepticism is proven limited, thus rendering human self-understanding, lest disclosed through speech acts and other forms of social interaction, an irrelevant element for analysis? As a celebration of the relational basis of social theory (cf. Yarrow et al. 2015), this 'sociological imagination' privileges socially 
Pre-copyedited version! Final version published in Ethnos 2016. Mette M. High

Please access it here: http://www.tandfonline.com/eprint/YJvhqgeRKljkdmR2Yl97/full

mediated action as the more reliable, if not objectifiable, realm within which human ethical self-formation occurs.

But this accent on the social, where humans become "surfaces to one another" and externalize themselves "in an objective form" (Keane 2010:69, 81), risks reproducing the deep and perhaps deepening separation of thought from action that Arendt (1958) saw as the besetting problem of the modern age. Attaching value to truth and objectivity, 'contemplation' becomes deceptive whereas 'making' becomes the grounds for experiments and observation. We should be wary of participating in these modernity projects when seeking to understand human encounters, unless we are willing to admit that we either see a concept of truth to underlie our disciplinary endeavors or agree to the demise of human contemplation. This is an ethical question crucial not only for Mongolia's mining lamas but for us all.

\section{Bibliography}

Arendt, H (1958) The Human Condition. Chicago: University of Chicago Press.

Arendt, H (1978a) The Life of the Mind, vol. 1: Thinking. New York: Harcourt Brace Jovanovich.

Arendt, H (1978b) The Life of the Mind, vol. 2: Willing. New York: Harcourt Brace Jovanovich.

Arendt, H (1982) Lectures on Kant's Political Philosophy. Chicago: University of Chicago Press.

Atwood, CP (2004) Encyclopedia of Mongolia and the Mongol Empire. New York: Facts on File Inc.

Author (2013a) Cosmologies of freedom and Buddhist self-transformation in the Mongolian gold rush. Journal of the Royal Anthropological Institute 19(4):753-770.

Author (2013b) Polluted money, polluted wealth: Emerging regimes of value in the Mongolian gold rush. American Ethnologist 40(4):676-688. 
Pre-copyedited version! Final version published in Ethnos 2016. Mette M. High

Please access it here: http://www.tandfonline.com/eprint/YJvhqgeRKljkdmR2Y197/full

Bareja-Starzynska A and Havnevik H (2006) A preliminary study of Buddhism in presentday Mongolia. In: Bruun O and Narangoa L (eds) Mongols from Country to City: Floating Boundaries, Pastoralism and City Life in the Mongol Lands. Copenhagen: NIAS Press, pp. 212-236.

Bubandt N and OttoT (2010) Anthropology and the predicaments of holism. In: Otto T and Bubandt N (eds) Experiments in Holism: Theory and Practice in Contemporary Anthropology. Oxford: Blackwell Publishing, pp. 1-16.

Cassiniti JL and Hickman JR (2014) New directions in the anthropology of morality. Anthropological Theory 14(3): $251-262$.

De Nebesky-Wojkowitz R (1956) Oracles and Demons of Tibet: The Cult and Iconography of the Tibetan Protective Deities. The Hague: Mouton \& Co.

Devenish, RP (2012) Principal Yogācāra Texts: Indo-Tibetan Sources of Dzogchen Mahāmudrā. Raleigh, N.C.: LuLu Press.

Durkheim E (2009 [1906]) The determination of moral facts. In: Durkheim E (ed) Sociology and Philosophy. Transl. by Pocock DF. London: Routledge, pp. 35-62.

Fassin D (2008) Beyond good and evil? Questioning the anthropological discomfort with morals. Anthropological Theory 8(4): 333-344.

Faubion JD (2011) An Anthropology of Ethics. Cambridge: Cambridge University Press. Harvey P (2001) An Introduction to Buddhist Ethics: Foundations, Values and Issues. Cambridge: Cambridge University Press.

Howell, S (1997) The Ethnography of Moralities. London: Routledge.

Humphrey C and Ujeed H (2012) Fortune in the wind: An impersonal subjectivity. Social Analysis 56(2):152-167.

Humphrey, C (1997) Exemplars and Rules: Aspects of the Discourse of Moralities in Mongolia. In: Howell S (ed) The Ethnography of Moralities. London: Routledge, pp. 25-48. 
Pre-copyedited version! Final version published in Ethnos 2016. Mette M. High

Please access it here: http://www.tandfonline.com/eprint/YJvhqgeRKljkdmR2Yl97/full

Jones J (2008) Blood that Cries Out from the Earth: The Psychology of Religious Terrorism. Oxford: Oxford University Press.

Kant I (2005 [1785]) The Moral Law: Groundwork of the metaphysic of morals. Transl. by Paton HJ. Oxford: Routledge.

Kaplonski, C (2008) Prelude to Violence: Show trials and state power in 1930s Mongolia. American Ethnologist 35(2):321-337.

Kaplonski, C (2012) Resorting to Violence: Technologies of Exception, Contingent States and the Repression of Buddhist Lamas in 1930s Mongolia. Ethnos 77(1): 72-92.

Keane, W (2010) Minds, Surfaces, and Reasons in the Anthropology of Ethics. In: Lambek M (ed) Ordinary Ethics: Anthropology, Language, and Action. New York: Fordham University Press, pp. 64-83..

Kochumuttom, TA (2008) A Buddhist Doctrine of Experience. Motilal Banarsidass: Delhi. Kollmar-Paulenz, K (2003) Buddhism in Mongolia after 1990. Journal of Global Buddhism 4:18-34.

Laidlaw J (2002) For an Anthropology of Ethics and Freedom. Journal of the Royal Anthropological Institute 8(2):311-332.

Laidlaw J (2010) Agency and responsibility: Perhaps you can have too much of a good thing. In: Lambek M (ed) Ordinary Ethics: Anthropology, Language, and Action. New York: Fordham University Press, pp. 143-164.

Laidlaw J (2014) The subject of Virtue: An anthropology of ethics and freedom. Cambridge: Cambridge University Press.

Lama, HH Dalai (1994) The Way to Freedom: Core Teachings of Tibetan Buddhism. San Francisco: Harper Collins.

Lambek M (2010a) Ordinary Ethics: Anthropology, Language, and Action. New York: Fordham University Press. 
Pre-copyedited version! Final version published in Ethnos 2016. Mette M. High

Please access it here: http://www.tandfonline.com/eprint/YJvhqgeRKljkdmR2Yl97/full

Lambek M (2010b) Introduction. In: Lambek M (ed) Ordinary Ethics: Anthropology,

Language, and Action. New York: Fordham University Press, pp. 1-38.

Lambek M (2010c) Toward an Ethics of the Act. In: Lambek M (ed) Ordinary Ethics:

Anthropology, Language, and Action. New York: Fordham University Press, pp. 39-63.

Lambek M (2015) On the Immanence of the Ethical: A response to Michael Lempert, 'No

Ordinary Ethics'. Anthropological Theory 15(2):128-132.

Mattingly, C (2012) Two Virtue Ethics and the Anthropology of Morality. Anthropological

Theory 12(2):161-184.

Mills, CW (2000) The Sociological Imagination. Oxford: Oxford University Press.

Ñāṇamoli B and Bodhi B (2001) The Middle Length Discourses of the Buddha: A

Translation of the Majjhima Nikāya. Oxford: Pali Text Society.

Povinelli, E (2001) Radical Worlds: The Anthropology of Incommensurability and

Inconceivability. Annual Review of Anthropology 30:319-334.

Robbins, J (2007) Between Reproduction and Freedom: Morality, value, and radical cultural change. Ethnos 72(3):293-314.

Roitman, J (2005) Fiscal Disobedience. Oxford: Princeton University Press.

Simmel, G (1903) The Metropolis and Mental Life. Chicago: University of Chicago Press.

Strathern M (1997) Double standards. In: Howell S (ed) The Ethnography of

Moralities. London: Routledge, pp. 127-151.

Thera N and Bodhi B (2011) Numerical Discourses of the Buddha: An Anthology of Suttas from the Anguttara-Nikāya. London: Yale University Press.

Toren, C and J de Pina-Cabral (2009) Introduction: what is happening to epistemology?. Social Analysis 53(2):1-18.

Victoria BD (2006) Zen at War. Lanham, MD.: Rowman and Littlefield Publishers.

Williams P (2009) Mahāyāna Buddhism: The Doctrinal Foundations. Oxford: Routledge. 
Pre-copyedited version! Final version published in Ethnos 2016. Mette M. High

Please access it here: http://www.tandfonline.com/eprint/YJvhqgeRKljkdmR2Yl97/full

Yan, Y (2011) How far away can we move from Durkheim?-Reflections on the new anthropology of morality. Anthropology of this Century issue 2, October.

Yarrow, T and M Candea, C Trundle, J Cook (2015) Detachment: Essays on the Limits of Relational Thinking. Manchester: Manchester University Press.

Zhengyin L (2003) Arts of the book, painting and calligraphy. Part three: Eastern Central Asia. In: Iskender-Mochiri I (ed) History of Civilizations of Central Asia. Vol. V.

Development in Contrast: From the Sixteenth to the Mid-Nineteenth Century. Paris:

UNESCO Publishing, pp. 610-628.

Zigon J (2007) Moral breakdown and the ethical demand: A theoretical framework for an anthropology of moralities. Anthropological Theory 7(2):131-150. 
Pre-copyedited version! Final version published in Ethnos 2016. Mette M. High

Please access it here: http://www.tandfonline.com/eprint/YJvhqgeRKljkdmR2Yl97/full

\section{Notes}

Acknowledgements. This article originally grew out of a paper that I presented at a conference entitled Freedoms and Liberties in Anthropological Perspective organized by Moises Lino E Silva and Huon Wardle in 2013. Benefitting from the great discussions and insightful comments, subsequent versions of this article were presented at the School of Divinity at University of Edinburgh, the Human Ecology Research Group at University College London, and the Social Anthropology Seminar Series on Markets, Moralities and the Politics of Possibility at the School of Oriental and African Studies. I am grateful to the participants of these seminars for their many helpful thoughts and questions. The article has further benefitted from detailed comments from Naomi Appleton, Marc Brightman, Adam Clarke, Tony Crook, Roy Dilley, Catherine Dolan, Richard Fardon, Sabine Hyland, Jean Lave, Jerome Lewis, Nigel Rapport, Adam Reed, Kelli Rudolph, Michael Scott, and Christina Toren. I would also like to thank the anonymous Ethnos reviewers for their perceptive and constructive comments. Fieldwork for this article was carried out in Uyanga, Central Mongolia, between 2005 and 2011. This would never have been possible without the help and friendship of my host Budlam, his wife Nergüi, their son Mönherdene, Tögslam, Lhagvadorj, Gansüh, Batsüren, Jagaanövgön, Ahaa, Baajiimaa, and the many households of Uyanga. Funding for this work was generously provided by the ESRC (PTA-030-2003-00784), the Wenner-Gren Foundation (Gr. 7376) and the British Academy (PDF/2009/423).

\footnotetext{
${ }^{1}$ Alongside Durkheim, these works also identify other scholarly legacies as burdens. Lambek discusses how Boas's "often-compelling identification of particular cultural values produced overly homogenous and bounded portraits, objectifying both individual values and the cultures they composed" (2010b:13, see also Fassin 2008:337) while Laidlaw highlights how, in Kantian ethics, "it is impossible... to see how specifically ethical considerations might be distinguishable" (2002:315).

${ }^{2}$ Although Lambek does give attention to issues of judgment, his interest in the relation of speakers to their words makes him approach judgment exclusively as part of social interaction and performance. Arendt, in contrast, develops roughly two conceptual models: Judging as a faculty of politically engaged actors who judge in order to act, and judging as a contemplative self-reflexive faculty of non-participating spectators who judge in order to cull meaning from the past. For Arendt (1978a, 1982), judgment is thus coeval with understanding, imagination and reconciliation - actions that do not necessarily rely on the spoken word.

${ }^{3}$ This is not to say that I do not recognise the importance of interaction and the spoken word when interlocutors later tell the anthropologist about their thoughts. However, although the enterprise of anthropology is premised on such dialogues to accompany observations and participations, this subsequent dialogue between interlocutor and anthropologist should not render insignificant people's initial contemplative actions.

${ }^{4}$ The Sanskrit word 'Dharma' is derived from the root 'dhŗ' which means 'to carry', 'to uphold' or 'to support'. In Buddhist terminology, it has various meanings ranging from the state of Nature "as it is" ( $\mathrm{Pa}$. yatha bhutā) to the teachings of the Buddha.

5 A version of this story is recounted by Buddha in Bālapaṇdita Sutta "Fools and Wise Men" in Majjhima Nikāya (Ñāṇamoli and Bodhi 2001:1016-1028). Buddha tells this story in order to convey to his followers how long it will take to regain a human bodily state from the realms of hell.

${ }^{6}$ In Uyanga the most commonly used word with a meaning equivalent to the English term 'volition' is zorilgoor. This expression is in the instrumental case and can be translated as 'with an aim', 'with a goal', 'with a purpose', thus used in expressions like zorilgoor hiisen üil ('an act done with a purpose'). Another word that is commonly used among the laity is sanaatai. This expression is in the comitative case and can be translated as 'with mind', 'with thoughts'.
} 


\footnotetext{
${ }^{7}$ The Mongolian word samadi is a loan word from the Sanskrit and Pāli samādhi, which can be translated literally as 'a putting or joining together' or 'to acquire integration or wholeness'. It denotes a state of meditative absorption or concentration.

${ }^{8}$ In establishing a critical distance to scriptures and teachers, Buddha is not rejecting the importance of his own teachings but rather showing the villagers its 'inherently true basis'.

${ }^{9}$ In referring to a lama as 'senior', I am not implying a greater progression along the path of liberation from suffering and achieving Enlightenment. Rather in a region where many members of the monastic community do not observe even the basic Five Precepts (Pa. pañcasílāni), the older the lama, the more senior and higher paid he is likely to be - almost regardless of his abilities to study scriptures, engage in devotional practice, or cultivate higher wisdom. Approaching seniority largely in terms of age is in continuation with the broader regional practice of patriarchal social organization.

${ }^{10}$ See specifically Compendium of Conduct in Shantideva's Śiksā-Samuccaya ("Training Anthology") and Stages of the Bodhisattva and Sutra on Skilful Means in Asanga's Mahāyāna-Samgraha ("Summary of the Mahāyāna").

${ }^{11}$ The Mongolian verb nomhotgoh is usually translated as 'to tame', 'to pacify'. It can also be translated as 'to break' in the sense of breaking horses, camels, etc.
} 